\title{
Sistem Pakar Diagnosis Penyakit Ayam Broiler Menggunakan Forward Chaining dan Certainty Factor
}

\author{
Anthony Anggrawan, Satuang, Mokhammad Nurkholis Abdillah
}

Universitas Bumigora, Indonesia

\section{Article Info}

Article history:

Received, 25 April 2020

Revised, 9 May 2020

Accepted, 28 May 2020

\section{Kata Kunci:}

Sistem Pakar

Diagnosis

Forward Chaining

Certainty Factor

Ayam Broiler

\begin{abstract}
ABSTRAK
Kesalahan mendiagnosis jenis penyakit menyebabkan kesalahan penanganan yang berdampak pada kematian. Hasil diagnosis membutuhkan derajat kepercayaan untuk menyakini hasilnya. Sistem pakar telah banyak digunakan untuk permasalahan diagnosis penyakit ayam broiler. Keterbatasan penelitian terdahulu pada kasus ini adalah dalam pemberian derajat kepercayaan seringkali hanya menggunakan nilai dari pakar. Peran pengguna hanya sebatas memilih gejala yang telah disediakan oleh sistem pakar tanpa memberikan penilaian bobot gejala yang dipilih, sehingga semua gejala dianggap pada kondisi ideal (keyakinan mutlak). Tujuan penelitian ini adalah mengembangkan purwarupa sistem pakar untuk diagnosis penyakit ayam broiler dengan menggabungkan metode forward chaining dan certainty factor, serta mengkombinasikan nilai bobot gejala dari pengguna dan pakar untuk meng-antisipasi kondisi tidak ideal. Tahapan penelitian terdiri dari pengumpulan data, pemodelan basis pengetahuan, implementasi dalam bentuk purwarupa berbasis web, dan pengujian. Hasil pengujian menunjukkan bahwa purwarupa sistem pakar menghasilkan diagnosis dengan tingkat validitas $100 \%$ ketika dibandingkan dengan perhitungan manual. Artinya purwarupa sudah sesuai rancangan. Selain itu, dampak pemberian nilai bobot gejala oleh pengguna berpengaruh terhadap turunnya nilai keyakinan hasil diagnosis bila dibandingkan kondisi ideal.
\end{abstract}

\section{ABSTRACT}

Mistakes in diagnosing type of disease lead to mishandling that has an impact on death. Results of diagnosis require a degree of confidence to believe in results. Expert systems have been widely used for problem of diagnosing broiler chickens. Limitation of previous research in this case is that in giving degrees of confidence, it often only uses expert value. Role of user is limited to selecting symptoms provided by expert system without giving an assessment of weight of symptoms selected, so that all symptoms are considered to be in ideal conditions (absolute confidence). Purpose of this study was to develop a prototype expert system for diagnosis of broiler chicken disease by combining forward chaining and certainty factor methods, and combining symptom weight values of users and experts to anticipate non-ideal conditions. Research stages consisted of data collection, knowledge base modeling, implementation in form of web-based prototypes, and testing. Test results show that expert system prototype produces a diagnosis with a validity level of $100 \%$ when compared to manual calculations. This means that prototype is according to design. In addition, weighting of symptoms by user has an effect on decline in value of confidence in diagnosis when compared to ideal conditions.

This is an open access article under the CC BY-SA license.

\section{Penulis Korespondensi:}

Mokhammad Nurkholis Abdillah, Program Studi Ilmu Komputer,

Universitas Bumigora.

Email: mnurkholisabdillah@universitasbumigora.ac.id 


\section{PENDAHULUAN}

Usaha peternakan ayam broiler memiliki prospek yang menjanjikan karena termsuk jenis ternak unggas dengan populasi terbesar pada tahun 2019. Bahkan tiap tahun semenjak 2015-2019 populasinya selalu meningkat rata-rata sekitar 400 ribu ekor per tahun [1]. Namun, memiliki risiko terjadi penurunan performa ayam karena penyakit [2]. Penyakit yang menyerang ternak unggas secara masal akan menyebabkan terjadinya penurunan populasi karena kematian dan turunnya volume penjualan [3] . Kondisi ayam broiler yang kurang sehat dapat diamati dari gejala-gejala fisik yang muncul dan untuk mengenalinya membutuhkan keahlian khusus karena tiap penyakit memiliki gejala-gejala yang mirip. Sayangnya, para peternak tersebut umumnya tidak memiliki pengetahuan memadai untuk mengenali penyakit yang menjangkiti ternak mereka. Disamping itu, keterbatasan jumlah tenaga ahli bidang kesehatan hewan di Indonesia juga menjadi penyebab penanganan ternak menjadi lambat. Hal tersebut membuat para peternak biasanya berinisiatif untuk melakukan penanganan sendiri sesuai dengan pengalaman yang mereka miliki.

Sistem pakar diusulkan untuk solusi diagnosis penyakit ayam broiler. Sistem pakar untuk diagnosis penyakit ayam broiler pada penelitian-penelitian sebelumnya memiliki beberapa kekurangan. Pada penelitian [4]-[7] tidak secara jelas menyatakan bahawa metode penalaran untuk mesin inferensinya menggunakan FC. Proses penalaran hanya membandingkan input gejala dengan daftar gejala yang dimiliki oleh penyakit tertentu pada basis pengetahuannya. Contoh pada penelitian [7] gejala "diare" dimiliki oleh empat jenis penyakit yaitu flu burung, marek, infeksi saluran pernapasan, dan kolibasilosis, sedangkan gejala "bulu kasar" berkaitan dengan penyakit kolibasilosis. Untuk mendiagnosis jenis penyakit yang tepat, semua aturan yang berkaitan dengan jenis penyakit tersebut akan disimpan dalam memori kerja untuk dievaluasi dan dihitung derajat kepercayaannya serta kemudian dirangking nilainya. Jika menggunakan FC, maka hanya aturan yang terkait penyakit kolibasilosis yang akan disimpan pada memori kerja untuk dievaluasi dan dihitung derajat kepercayaannya.

Penggunaan metode pengukuran derajat kepercayaan untuk diagnosis ayam broiler telah dilakukan pada penelitian [4] $-[\underline{8}]$. Penelitian [4]]-[] ], []] menggunakan metode CF sedangkan penelitian []] menggunakan metode DS. Kesamaan dari penelitian-penelitan tersebut adalah nilai bobot gejala untuk menentukan nilai akhir derajat kepercayaan hanya diperoleh dari pakar. Hal tersebut menyiratkan makna bahawa pengguna sistem pakar secara mutlak dianggap sangat menyakini gejala-gejala fisik penyebab kelainan pada ayam dengan pasti. Namun, asumsi tersebut hanya cocok untuk kondisi ideal dan kenyataanya pengguna tidak bisa meyakini secara sempurna gejala-gejala fisik tersebut melainkan dengan nilai perkiraan misalnya "tidak yakin", "cukup yakin", atupun "sangat yakin". Pada penelitian [9] hanya menggunakan metode penalaran FC dan tidak menggunakan metode untuk mengukur derajat kepercayaan. Sehingga sistem pakar yang dikembangkan tidak mampu memberikan rasa keyakinan terhadap hasil diagnosis. Perbandingan penelitian-penelitian sebelumnya tersebut disajikan pada Tabel 1.

Tabel 1. Penelitian-Penelitian Sebelumnya Terkait Sistem Pakar Ayam Broiler

\begin{tabular}{|c|c|c|c|c|c|}
\hline Referensi & $\begin{array}{l}\text { Jumlah } \\
\text { Penyakit }\end{array}$ & Jenis penyakit & $\begin{array}{c}\text { Metode } \\
\text { Penalaran } \\
\end{array}$ & $\begin{array}{c}\text { Metode } \\
\text { Keyakinan }\end{array}$ & Implementasi \\
\hline [4] & 3 & gumboro, berak kapur, berak darah & -- & $\begin{array}{l}\text { CF (MB dan } \\
\text { MD) (bobot dari } \\
\text { pakar) }\end{array}$ & Website \\
\hline$[\underline{5}]$ & 6 & $\begin{array}{l}\text { gumboro, berak kapur, kolera, tetelo, } \\
\text { ngorok, snot, kolibasilosis, bronchitis, flu } \\
\text { burung, marek }\end{array}$ & -- & $\begin{array}{l}\text { CF (MB dan } \\
\text { MD) (bobot dari } \\
\text { pakar) }\end{array}$ & Tidak dinyatakan \\
\hline [6] & 1 & gumboro & -- & $\begin{array}{l}\text { CF (bobot dari } \\
\text { pakar ) }\end{array}$ & Tidak dinyatakan \\
\hline [7] & 10 & $\begin{array}{l}\text { gumboro, berak kapur, kolera, tetelo, } \\
\text { ngorok, snot, kolibasilosis, bronchitis, flu } \\
\text { burung, marek }\end{array}$ & -- & $\begin{array}{c}\text { DS (bobot dari } \\
\text { pakar) }\end{array}$ & Android \\
\hline [9] & 15 & $\begin{array}{l}\text { gumboro, berak kapur, berak darah, } \\
\text { kolera, tetelo, ngorok, snot, kolibasilosis, } \\
\text { malaria, bronchitis, busung perut, flu } \\
\text { burung, cacingan, tungau, penyakit pusar }\end{array}$ & $\mathrm{FC}$ & -- & $\begin{array}{l}\text { Sistem otomasi } \\
\text { dan android }\end{array}$ \\
\hline
\end{tabular}


Berdasarkan uraian diatas, tujuan dari penelitian ini adalah mengembangkan purwarupa sistem pakar untuk mendiagnosis penyakit pada ayam broiler yang mengakomodasi peran pengguna dalam pemberian nilai bobot gejala untuk mengantisipasi kondisi dimana pengguna merasa tidak memiliki keyakinan mutlak (kondisi ideal) terhadap gejala yang dipilih. Sistem pakar dibuat dengan menerapkan metode penalaran menggunakan forward chaining dan metode pengukuran derajat kepercayaan dengan certainty factor. Pertimbangan menggunakan metode forward chaining karena untuk mendiagnosis penyakit membutuhkan info mengenai gejala-gejala yang dialami dan metode ini mampu memfilter aturan-aturan yang akan dievaluasi pada memori kerja. Pemilihan metode certainty factor berdasarkan penelitian [10]-[12] yang menyatakan metode ini memliki nilai derajat kepercayaan tertinggi dibandingkan teorema bayes, dempster shafer dan fuzzy mamdani. Selain itu, dalam penelitian ini penentuan nilai akhir certainty factor mengkombinasikan nilai bobot gejala yang diperoleh dari pengguna dan juga pakar untuk mengantisipasi kondisi ideal yang tidak selalu terjadi ketika pengguna menggunakan sistem pakar. Kondisi ideal yang dimaksud dalam penelitian ini adalah suatu kondisi dimana gejala fisik benar-benar dialami oleh ayam dengan keyakinan mutlak (sangat yakin atau bernilai 1) menurut pengamatan pengguna. Misalnya dalam suatu pengamatan ayam terlihat mengalami gejala "nafsu makan menurun", dalam pengamatan pengguna bisa saja gejala tersebut tidak diyakini dengan keyakinan mutlak tetapi "cukup yakin" ataupun "kurang yakin". Sistem pakar akan diimplementasikan dalam bentuk purwarupa berbasis web.

\section{METODE PENELITIAN}

Jenis metode penelitian yang digunakan dalam penelitian ini adalah eksperimen. Secara garis besar proses penelitian ini dimulai dari identifikasi masalah, pengumpulan data, pembuatan basis pengetahuan, implementasi, serta terakhir eksperimen pengujian. Tahapan atau langkah-langkah yang dilakukan dalam penelitian ini dapat dilihat pada Gambar 1 .

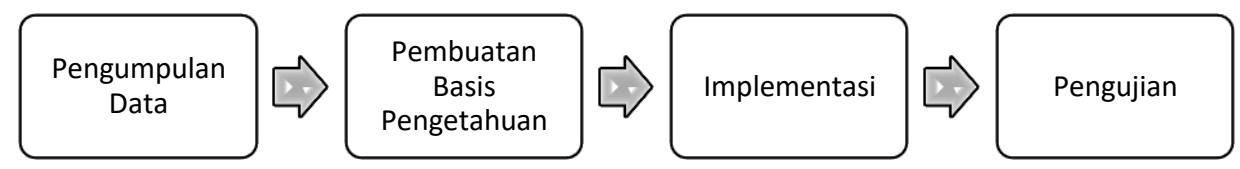

Gambar 1. Tahapan penelitian

\subsection{Pengumpulan Data}

Proses pengumpulan data dilakukan dengan melakukan wawancara kepada orang yang ahli pada bidang kesehatan hewan yaitu dokter hewan yang bernama drh. Suradi. Narasumber hanya menggunakan satu orang karena setiap orang memiliki pandangan yang berbeda-beda terhadap suatu jenis penyakit dan untuk memudahkan dalam pembuatan model pengetahuan. Ada dua kategori data yang dibutuhkan, yaitu data penyakit dan data gejala. Untuk data penyakit ayam broiler terdiri dari enam jenis penyakit baik yang disebabkan oleh bakteri maupun virus. Daftar data penyakit disajikan pada Tabel 2.

Tabel 2. Data Penyakit

\begin{tabular}{|c|c|c|}
\hline Kode Penyakit & Nama Penyakit & Nama Ilmiah \\
\hline $\mathrm{P} 1$ & Ngorok & Cronic Respiratory Disease (CRD) \\
\hline $\mathrm{P} 2$ & Tetelo & Newcastle Disease (ND) \\
\hline P3 & Gumboro & Infectious Bursal Disease (IBD) \\
\hline $\mathrm{P} 4$ & Berak Kapur & Pullorum \\
\hline P5 & Flu Burung & Avian Influenza (AI) \\
\hline
\end{tabular}

Untuk data gejala yang biasa dialami oleh ayam broiler terdiri dari 31 buah. Daftar data gejala disajikan pada Tabel 3. 
Tabel 3. Data Gejala

\begin{tabular}{|c|c|c|c|}
\hline Kode Gejala & Nama Gejala & Kode Gejala & Nama Gejala \\
\hline G1 & Ngorok basah & G17 & Bulu tampak kusam \\
\hline G2 & Leleran hidung lengket & G18 & $\begin{array}{l}\text { Diare berlendir mengotori } \\
\text { bulu pantat }\end{array}$ \\
\hline G3 & $\begin{array}{l}\text { Terdapat eskudat berbuih pada } \\
\text { mata }\end{array}$ & G19 & $\begin{array}{l}\text { Peradangan di sekitar } \\
\text { dubur dan kloaka }\end{array}$ \\
\hline G4 & Menggeleng-gelengkan kepala & $\mathrm{G} 20$ & Mematok dubur sendiri \\
\hline G5 & Mengeluarkan nanah dari hidung & G21 & $\begin{array}{l}\text { Paruh menempel di lantai } \\
\text { ketika tidur }\end{array}$ \\
\hline G6 & Mengengap-engap & $\mathrm{G} 22$ & Kotoran berwarna putih \\
\hline G7 & Batuk & $\mathrm{G} 23$ & $\begin{array}{l}\text { Kotoran menempel di } \\
\text { sekitar dubur }\end{array}$ \\
\hline G8 & Bersin & G24 & Kloaka tampak putih \\
\hline G9 & $\begin{array}{l}\text { Ayam tampak lesu dan } \\
\text { mengantuk }\end{array}$ & $\mathrm{G} 25$ & $\begin{array}{l}\text { Jengger berwarna } \\
\text { keabuan }\end{array}$ \\
\hline G10 & Nafsu makan menurun & G26 & Mata menutup \\
\hline G11 & Mencret & $\mathrm{G} 27$ & Luka bergerombol \\
\hline G12 & Jengger dan kepala kebiruan & $\mathrm{G} 28$ & Lumpuh \\
\hline G13 & Kornea menjadi keruh & G29 & Pendarahan gusi \\
\hline G14 & Sayap turun & G30 & Pendarahan hidung \\
\hline G15 & Otot tubuh gemetar & G31 & Nyeri dada \\
\hline G16 & Kejang-kejang & & \\
\hline
\end{tabular}

\subsection{Pembuatan basis pengetahuan}

Basis pengetahuan digunakan untuk memodelkan atau mengkodekan data-data pengetahuan hasil akuisi dari pakar menjadi bentuk yang mudah dipahami [13]. Pada tahap ini setiap data penyakit ayam broiler dikorelasikan dengan gejala-gejalanya. Setiap gejala yang dikorelasikan tersebut diberikan nilai derajat kepercayaan dimana nilainya ditentukan oleh pakar. Jadi besarnya nilai bobot gejala tergantung pada penilaian pakar yang menjadi narasumber penelitian ini. Nilai bobot setiap gejala dalam rentang $0-1$. Model basis pengetahuan pada penelitian ini disajikan pada Tabel 4 dimana kode P1-P5 mengacu pada Tabel 2.

Tabel 4. Basis Pengetahuan

\begin{tabular}{|c|c|c|c|c|c|c|}
\hline Kode & Nama Gejala & P1 & $\mathbf{P 2}$ & P3 & P4 & P5 \\
\hline G1 & Ngorok basah & 0,9 & & & & \\
\hline $\mathrm{G} 2$ & Leleran hidung lengket & 0,7 & & & & \\
\hline G3 & Terdapat eskudat berbuih pada mata & 0,5 & & & & \\
\hline G4 & Menggeleng-gelengkan kepala & 0,3 & & & & \\
\hline G5 & Mengeluarkan nanah dari hidung & 0,4 & & & & \\
\hline G6 & Mengengap-engap & & 0,8 & & & \\
\hline G7 & Batuk & & 0,7 & & & \\
\hline G8 & Bersin & & 0,7 & & & \\
\hline G9 & Ayam tampak lesu dan mengantuk & & 0,4 & 0,4 & 0,6 & \\
\hline G10 & Nafsu makan menurun & & 0,5 & 0,2 & 0,2 & \\
\hline G11 & Mencret & & 0,3 & & & \\
\hline G12 & Jengger dan kepala kebiruan & & 0,3 & & & \\
\hline G13 & Kornea menjadi keruh & & 0,2 & & & \\
\hline G14 & Sayap turun & & 0,7 & & 0,7 & \\
\hline G15 & Otot tubuh gemetar & & 0,6 & & & \\
\hline G16 & Kejang-kejang & & 0,6 & & & \\
\hline G17 & Bulu tampak kusam & & & 0,4 & 0,8 & \\
\hline G18 & Diare berlendir mengotori bulu pantat & & & 0,6 & & 0,2 \\
\hline G19 & Peradangan di sekitar dubur dan kloaka & & & 0,6 & & \\
\hline $\mathrm{G} 20$ & Mematok dubur sendiri & & & 0,5 & & \\
\hline $\mathrm{G} 21$ & Paruh menempel di lantai ketika tidur & & & 0,9 & & \\
\hline $\mathrm{G} 22$ & Kotoran berwarna putih & & & 0,2 & 0,9 & \\
\hline $\mathrm{G} 23$ & Kotoran menempel di sekitar dubur & & & & 0,8 & \\
\hline $\mathrm{G} 24$ & Kloaka tampak putih & & & & 0,8 & \\
\hline $\mathrm{G} 25$ & Jengger berwarna keabuan & & & & 0,4 & \\
\hline G26 & Mata menutup & & & & 0,3 & \\
\hline $\mathrm{G} 27$ & Luka bergerombol & & & & 0,3 & \\
\hline $\mathrm{G} 28$ & Lumpuh & & & & & 0,5 \\
\hline G29 & Pendarahan gusi & & & & & 0,7 \\
\hline $\mathrm{G} 30$ & Pendarahan hidung & & & & & 0,7 \\
\hline
\end{tabular}


Model basis pengetahuan pada Tabel 4 kemudian direpresentasikan menggunakan kaidah produksi atau production rule dalam bentuk $I F-T H E N$. Kaidah produksi terdiri dari bagian fakta-fakta gejala atau dikenal dengan anteseden dan bagian kesimpulan penyakit atau konsekuen [14]. Pada penelitian ini kaidah produksi menghasilkan lima buah aturan seperti yang terlihat pada Tabel 5 .

Tabel 5. Aturan

\begin{tabular}{|c|c|}
\hline Kode Aturan & Aturan IF-THEN \\
\hline $\mathrm{R} 1$ & IF G1 AND G2 AND G3 AND G4 AND G5 THEN P1 \\
\hline $\mathrm{R} 2$ & $\begin{array}{l}\text { IF G6 AND G7 AND G8 AND G9 AND G10 AND G11 AND G12 AND G13 AND G14 AND G15 AND } \\
\text { G16 THE } \boldsymbol{A} \text { P2 }\end{array}$ \\
\hline R3 & IF G9 AND G10 AND G17 AND G18 AND G19 AND G20 AND G21 AND G28 THEN P3 \\
\hline $\mathrm{R} 4$ & $\begin{array}{l}\text { IF G9 AND G10 AND G14 AND G17 AND G22 AND G23 AND G24 AND G25 AND G26 AND G27 } \\
\text { THEN P4 }\end{array}$ \\
\hline R5 & $\boldsymbol{I F} \mathrm{G} 18 \boldsymbol{A} \boldsymbol{N D} \mathrm{G} 28 \boldsymbol{A} \boldsymbol{N D} \mathrm{G} 29 \boldsymbol{A} \boldsymbol{N D} \mathrm{G} 30 \boldsymbol{A} \boldsymbol{N D} \mathrm{G} 31 \boldsymbol{T H} \boldsymbol{N} \boldsymbol{N} \mathrm{P} 5$ \\
\hline
\end{tabular}

\subsection{Implementasi}

Pada tahap implementasi aktifitas yang dilakukan adalah mengkonversikan model pengetahuan yang telah dibuat ke dalam suatu purwarupa. Arsitektur purwarupa dari sistem pakar yang dibangun menyadur dari penelitian [15] dimana terdiri dari enam komponen yaitu antarmuka pengguna, fasilitas akusisi pengetahuan, basis pengetahuan, mesin inferensi, dan memori kerja. Arsitektur purwarupa diperlihatkan pada Gambar 2.

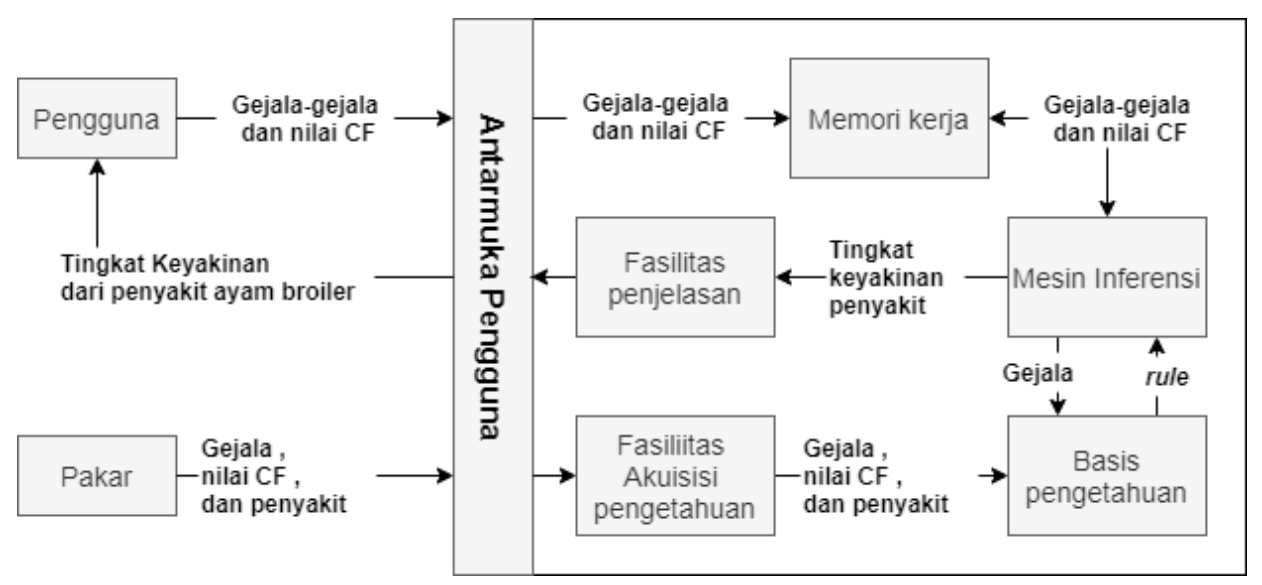

Gambar 2. Arsitektur sistem pakar ayam broiler

Komponen antarmuka digunakan oleh pakar maupun pengguna untuk berinteraksi dengan sistem. Pakar dapat mengelola (tambah, ubah, dan hapus) data pengetahuan (gejala, nilai $\mathrm{CF}$, dan jenis penyakit) melalui fasilitas akuisisi pengetahuan yang nantinya akan menjadi model untuk komponen basis pengetahuan. Komponen mesin inferensi melakukan proses penalaran dengan membaca data-data gejala pada komponen memori kerja untuk dicocokkan dengan basis pengetahuan. Komponen memori kerja digunakan untuk menampung data-data gejala yang dimasukkan oleh pengguna agar dapat diolah oleh mesin inferensi.

Pada penelitian ini metode forward chaining digunakan dalam mesin inferensi. Mesin inferensi bertugas menarik suatu kesimpulan jenis penyakit dengan menganalisis basis pengetahuan berdasarkan masukan gejalagejala yang diberikan oleh pengguna. Metode forward chaining akan melakukan proses penalaran dimulai dari keadaan awal (mengumpulkan informasi atau fakta yang ada) untuk kemudian melakukan pencocokkan dengan tujuan atau kesimpulan yang diharapkan [14], [16].

Untuk memberikan derajat kepastian suatu fakta atau aturan hasil dari penelusuran mesin inferensi menggunakan metode certainty factor. Metode ini memiliki kelebihan dapat menghindari inkonsitensi dalam pengambilan kesimpulan [15]. Penelitian ini menggunakan dua jenis sumber nilai $\mathrm{CF}$, yaitu nilai yang diberikan oleh pengguna $\left(C F_{\text {user }}\right)$ dan pakar $\left(C F_{\text {pakar }}\right)$. Untuk nilai $C F_{\text {pakar }}$ dapat dilihat pada Tabel 4 , sedangkan nilai $C F_{\text {user }}$ mengacu pada Tabel 6. 


\begin{tabular}{cc} 
Tabel 6. Nilai Certainty Factor & Pengguna $\left(C F_{\text {use }}\right)$ \\
\cline { 2 - 2 } \multicolumn{1}{c}{ Kondisi } & Nilai CF \\
\cline { 2 - 2 } Tidak yakin & 0,1 \\
Hampir tidak yakin & 0,2 \\
Kemungkinan besar tidak yakin & 0,3 \\
Mungkin tidak yakin & 0,4 \\
Tidak tahu & 0,5 \\
Mungkin & 0,6 \\
Kemungkinan besar & 0,7 \\
Hampir yakin & 0,8 \\
Yakin & 0,9 \\
Sangat yakin & 1 \\
\hline
\end{tabular}

Pada penelitian ini perhitungan nilai CF akhir suatu hipotesis menggunakan konsep kombinasi. Konsep ini digunakan karena mempertimbangkan adanya dua buah aturan (bahkan lebih) dengan gejala-gejala berbeda tetapi memiliki hipotesis sama. Proses penghitungan nilai CF-nya melalui dua tahapan, yaitu secara paralel dan kombinasi [10], [18]. Tahap pertama menghitung nilai $\mathrm{CF}$ suatu gejala secara paralel $\left(C F_{\text {paralel }}\right)$ dengan melakukan perkalian antara nilai $C F_{\text {user }}$ dengan nilai $C F_{\text {pakar }}$ seperti pada persamaan (1). Tahap kedua menggunakan hasil perhitungan $C F_{\text {parale }}$ untuk menentukan nilai $C F$ kombinasi $\left(C F_{\text {kombinasi }}\right)$ menggunakan persamaan (2). Proses perhitungan pada tahap kedua ini dilakukan secara berulang-ulang sesuai dengan banyaknya masukan jumlah gejala. Syarat utama untuk menggunakan persamaan (1) dan (2) adalah nilai CF baik dari pengguna maupun pakar harus lebih dari nol $\left(C F_{\text {user }}\right.$ dan $\left.C F_{\text {pakar }}>0\right)[12]$.

$$
\begin{aligned}
& C F(H \mid E)_{\text {paralel }}=C F(E)_{\text {user }} \times C F(E)_{\text {pakar }} \\
& C F\left(H \mid C F_{1}, C F_{2}\right)_{\text {kombinasi }}=C F_{1}+C F_{2}\left(1-C F_{1}\right)
\end{aligned}
$$

dimana:

$C F(H \mid E)_{\text {paralel }}=$ nilai certainty factor paralel hipotesis $\mathrm{H}$ jika diberikan gejala atau evidence $\mathrm{E}$

$C F(E)_{\text {user }}=$ nilai certainty factor dari gejala atau evidence $\mathrm{E}$ yang diberikan oleh pengguna

$C F(E)_{\text {pakar }}=$ nilai certainty factor dari gejala atau evidence $\mathrm{E}$ yang diberikan oleh pakar

$C F\left(H \mid C F_{1}, C F_{2}\right)_{\text {kombinasi }}=$ nilai certainty factor kombinasi gejala atau evidence $\mathrm{E}$ pada hipotesis $\mathrm{H}$

Tahap akhir dari implementasi adalah pengimplentasian metode forward chaining dan certainty factor untuk membangun sistem pakar dalam bentuk purwarupa berbasis web mengunakan bahasa pemrograman PHP dan basisdata MySQL.

\subsection{Pengujian}

Pada tahap pengujian ada dua hal yang diuji (Gambar 3), yaitu (1) pengujian validasi output sistem pakar dan (2) pengujian untuk mengetahui dampak penggunaan nilai $C F_{u s e r}$.

$$
\text { Uji validasi output sistem pakar }
$$
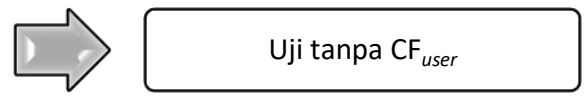

Gambar 3. Tahapan pengujian

Pengujian validasi output sistem pakar dilakukan untuk dua hal, yaitu pertama membandingkan antara hasil diagnosis sistem dengan rancangan model basis pengetahuan dan kedua membandingkan nilai kepercayaan dari sistem pakar dengan hasil perhitungan manual. Hasil akhir perbandingan dihitung dengan persamaan (3) untuk mengetahui persentase kesesuaian sistem dengan rancangan. Tujuan dari pengujian ini adalah untuk memastikan output yang dihasilkan oleh purwarupa sistem pakar sudah benar sesuai dengan rancangan pada model basis pengetahuan.

$$
\text { Validasi }_{\text {output }}=\frac{R_{\text {sesuai }} \text { atau } C F_{\text {sesuai }}}{U_{\text {total }}} \times 100 \%
$$

dimana:

Validasi $_{\text {output }}=$ nilai persentase kesesuaian antara output manual dengan output sistem

$R_{\text {sesuai }} \quad=$ hasil pengujian kesesuaian rule antara basis pengetahuan dengan sistem 
$\mathrm{CF}_{\text {sesuai }} \quad=$ hasil pengujian derajat kepercayaan yang sesuai antara hitung manual dengan sistem

$U_{\text {total }} \quad=$ jumlah total percobaan

Pengujian tanpa nilai $C F_{\text {user }}$ dilakukan dengan tujuan mengetahui bagaimana dampak nilai derajat kepercayaannya bila dibandingkan dengan hasil pengujian yang menggunakan nilai $C F_{\text {user }}$. Skenario pengujian tanpa $C F_{\text {user }}$ dilakukan dengan mengatur input nilai bobot gejala oleh pengguna diberikan nilai mutlak (bernilai 1 atau sangat yakin). Kondisi nilai mutlak menyatakan bahwa gejala yang diamati oleh pengguna benar-benar dialami oleh ayam dengan sebenar-benarnya terjadi (asumsi kondisi ideal).

\section{HASIL DAN ANALISIS}

Secara umum proses menentukan hasil diagnosis pada sistem pakar diperlihatkan pada Gambar 4a. Proses awal adalah memilih daftar gejala dan menentukan nilai CF-nya (Gambar 4). Gejala-gejala yang telah dipilih tersebut kemudian digunakan oleh mesin inferensi sebagai dasar untuk melakukan penelusuran aturan pada basis pengetahuan (Gambar 3b). Output dari mesin inferensi adalah jenis penyakit. Jenis penyakit tersebut kemudian dihitung derajat keyakinannya menggunakan persamaan (1) dan persaamaan (2). Hasil perhitungan tersebut akan ditampilkan ke pengguna.

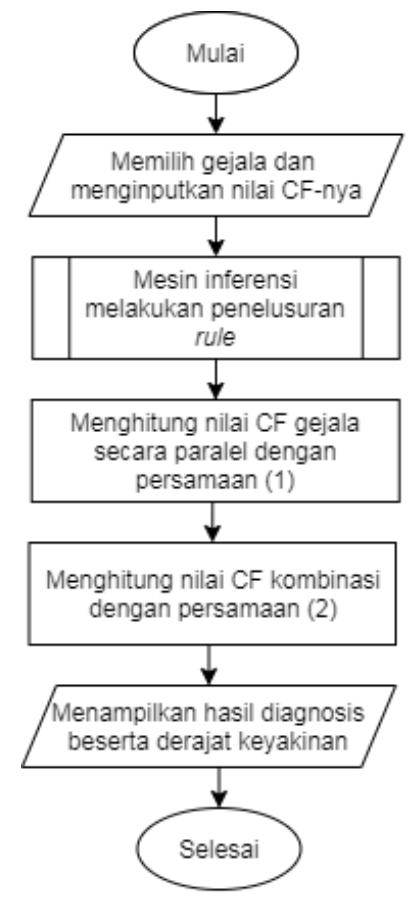

a

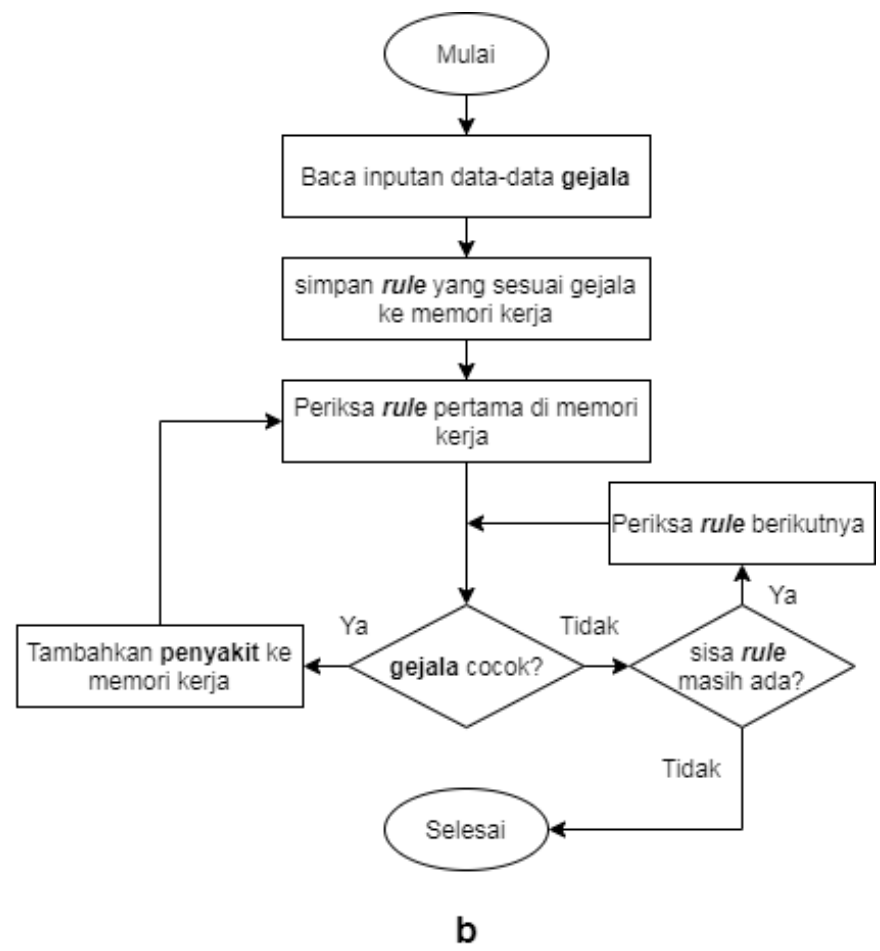

Gambar 4. Prinsip kerja sistem pakar (a), prosedur kerja mesin inferensi (b)

Proses kerja dari mesin inferensi (Gambar 4b) menggunakan metode forward chaining. Mesin inferensi menggunakan gejala-gejala yang dipilih pengguna untuk memfilter aturan-aturan yang akan diuji sehingga tidak semua aturan akan ditelusuri. Aturan-aturan terpilih tersebut dimasukkan ke dalam memori kerja dalam bentuk antrian (queue). Input gejala akan dicocokan dengan aturan pertama (sesuai daftar antrian) di memori kerja. Jika gejala ditemukan pada aturan tersebut, jenis penyakit disimpan ke dalam memori kerja. Kemudian memeriksa gejala berikutnya. Jika gejala berikutnya ternyata tidak cocok dengan aturan pertama, gejala tersebut dicocokan dengan aturan berikutnya. Apabila gejala tersebut cocok dengan aturan kedua, jenis penyakit terbaru ditambahkan ke memori kerja dan seterusnya sampai gejala sudah habis.

\subsection{Antarmuka Halaman Konsultasi}

Pengguna melakukan konsultasi mengenai penyakit ayam broiler menggunakan antaramuka halaman konsultasi (Gambar 5). Pada halaman ini semua daftar gejala ditampilkan dan pengguna dapat memilih gejalagejala yang dialami ayam broiler. Setiap memilih gejala harus memberikan nilai $C F_{u s e r}$ sesuai Tabel 6. 


\begin{tabular}{|c|c|c|}
\hline \multicolumn{2}{|c|}{ Gejala Pada Ayam } & Tingkat Kyakinan Atas Gejala \\
\hline$\square$ & Ngorok Basah & Nilai CF $\quad$ \\
\hline$\square$ & Nafsu Makan Menurun & Nilai CF $\quad$ \\
\hline$\square$ & Mencret & Nilai CF $\quad-$ \\
\hline$\square$ & Jenger Dan Kepala Kebiruan & Nilai CF $\quad$ \\
\hline$\square$ & Kornea Menjadi Keruh & Nilai CF \\
\hline$\square$ & Sayap Turun & Nilai CF \\
\hline
\end{tabular}

Gambar 5. Antarmuka halaman konsultasi

\subsection{Simulasi Pengujian Sistem Pakar}

Pada simulasi untuk menguji hasil diagnosis sistem pakar menggunakan tujuh buah gejala yang dipilih secara acak dan pemberian nilai $C F_{\text {user }}$ tiap gejala mengacu pada Tabel 6. Daftar input gejala untuk simulasi pengujian disajikan pada Tabel 7 .

Tabel 7. Simulasi Input Gejala

\begin{tabular}{clc}
\hline Kode Gejala & \multicolumn{1}{c}{ Gejala } & Nilai CFuser \\
\hline G8 & Bersin & 0,6 \\
G9 & Ayam tampak lesu dan mengantuk & 0,7 \\
G10 & Nafsu makan menurun & 0,8 \\
G17 & Bulu tampak kusam & 0,5 \\
G22 & Kotoran berwarna putih & 0,6 \\
G24 & Kloaka tampak putih & 0,8 \\
G26 & Mata menutup & 0,5 \\
\hline
\end{tabular}

Mesin inferensi menggunakan data input gejala pada Tabel 7 sebagai dasar untuk memproses penelusuran rule (Tabel 5) mengikuti diagram alir pada Gambar 3b. Pada iterasi ke-1 mesin inferensi mencocokan gejala G8 dengan data gejala pada aturan R2 dan ada kecocokan sehingga konklusi P2 (Newcastle Disease) disimpan dalam memori kerja. Untuk iterasi ke-2 dan ke-3 mirip dengan iterasi ke-1. Pada iterasi ke-4 data gejala G17 dicocokan dengan data gejala pada aturan R2 dan ternyata tidak cocok sehingga aturan R2 dihapus dari memori kerja. Gejala G17 kemudian dicocokkan dengan data gejala pada aturan R3 dan ada kecocokan sehingga konklusi P3 (Gumboro) disimpan dalam memori kerja. Hasil lengkap dari penelusuran mesin inferensi ditunjukkan pada Tabel 8 dan hasil diagnosis adalah P4 (Berak Kapur).

Tabel 8. Proses Mesin Inferensi

\begin{tabular}{ccccc}
\hline Iterasi ke- & Input Gejala & $\begin{array}{c}\text { Antrian Memori } \\
\text { Kerja }\end{array}$ & $\begin{array}{c}\text { Aturan di } \\
\text { Evaluasi }\end{array}$ & Konklusi \\
\hline 1 & G8 & R2, R3, R4 & R2 & P2 \\
2 & G9 & R2, R3, R4 & R2 & P2 \\
3 & G10 & R2, R3, R4 & R2 & P2 \\
4 & G17 & R2, R3, R4 & R3 & P3 \\
5 & G22 & R2, R3, R4 & R3 & P3 \\
6 & G24 & R2, R3, R4 & R4 & P4 \\
7 & G26 & R2, R3, R4 & R4 & P4 \\
\hline
\end{tabular}

Untuk memberikan derajat keyakinan terhadap hasil penalaran mesin inferensi dilakukan perhitungan nilai CF-nya. Hasil penelusuran mesin inferensi mendapatkan diagnosis jenis penyakit ayam broiler adalah P2 (berak kapur). Pada basis pengetahuan (Tabel 4) penyakit berak kapur memiliki 9 gejala sedangkan input gejala dari pengguna yang cocok dengan penyakit ini ada 5. Kelima input gejala dari pengguna tersebut yaitu nafsu makan menurun (G10), bulu tampak kusam (G17), kotoran berwaran putih (G22), kloaka tampak putih (G24), dan mata menutup (G26) digunakan untuk menghitung $C F_{\text {parale }}$ menggunakan persamaan (1). Hasil seluruh perhitungan $C F_{\text {paralel }}$ disajikan pada Tabel 9 dan nilai 0 pada $C F_{u s e r}$ artinya gejala tidak dipilih pengguna. 
Tabel 9. Nilai $C F_{\text {Paralel }}$

\begin{tabular}{cccrcrc}
\hline Konklusi & Gejala & CFpakar & CFuser & Perhitungan & CFparalel & Kode CF \\
\hline \multirow{6}{*}{ G4 } & 0,6 & 0 & & 0 & \\
& G10 & 0,2 & $\mathbf{0 , 8}$ & $0,2 \times \mathbf{0 , 8}$ & $\underline{\mathbf{0 , 1 6}}$ & $\mathrm{CF}_{1}$ \\
& $\mathrm{G} 14$ & 0,7 & 0 & & $\mathbf{0}$ & \\
& $\mathrm{G} 17$ & 0,8 & $\mathbf{0 , 5}$ & $0,8 \times \mathbf{0 , 5}$ & $\underline{\mathbf{0 , 4}}$ & $\mathrm{CF}_{2}$ \\
& $\mathrm{G} 22$ & 0,9 & $\mathbf{0 , 6}$ & $0,9 \times \mathbf{0 , 6}$ & $\underline{\mathbf{0 , 5 4}}$ & $\mathrm{CF}_{3}$ \\
& $\mathrm{G} 23$ & 0,8 & 0 & & & \\
& $\mathrm{G} 24$ & 0,8 & $\mathbf{0 , 8}$ & $0,8 \times \mathbf{0 , 8}$ & $\underline{\mathbf{0 , 6 4}}$ & $\mathrm{CF}_{4}$ \\
& $\mathrm{G} 25$ & 0,4 & 0 & & $\mathbf{0}$ & \\
& $\mathrm{G} 26$ & 0,3 & $\mathbf{0 , 5}$ & $0,3 \times \mathbf{0 , 5}$ & $\mathbf{0 , 1 5}$ & $\mathrm{CF}_{5}$ \\
& $\mathrm{G} 27$ & 0,3 & 0 & & & \\
\hline
\end{tabular}

Hasil perhitungan $C F_{\text {paralel }}$ digunakan untuk menghitung $C F_{\text {kombinasi }}$ menggunakan persamaan (2). Rekap hasil seluruh perhitungan $C F_{\text {kombinasi }}$ disajikan pada Tabel 10. Pada Tabel 10 untuk iterasi ke-1 nilai $C F_{a k h i r}$ dihitung dari nilai $C F_{l}$ dan $C F_{2}$ pada Tabel 9. Hasil $C F_{\text {akhir }}$ pada iterasi ke-1 diberi nama $C F_{A}$. Pada iterasi ke2 nilai $C F_{a k h i r}$ dihitung dari nilai $C F_{A}$ (Tabel 10) dan $C F_{3}$ (Tabel 9). Hasil $C F_{\text {akhir }}$ pada iterasi ke-2 diberi nama $C F_{B}$. Proses tersebut akan diulang sesuai jumlah iterasi yang dibutuhan.

Tabel 10. Nilai $C F_{\text {Kombinasi }}$

\begin{tabular}{ccrrr}
\hline Iterasi ke- & $\mathbf{C F}$ & \multicolumn{1}{c}{ Perhitungan } & CFakhir & Kode CFakhir \\
\hline 1 & $\mathrm{CF}\left(\mathbf{C F}_{\mathbf{1}}, \mathrm{CF}_{2}\right)$ & $\mathbf{0 , 1 6}+0,4 \times(1-\mathbf{0 , 1 6})$ & $\mathbf{0 , 4 9 6}$ & $\mathbf{C F}_{\mathbf{A}}$ \\
& $\mathrm{CF}\left(\mathrm{CF}_{\mathbf{A}}, \mathrm{CF}_{3}\right)$ & $\mathbf{0 , 4 9 6}+0,54 \times(1-\mathbf{0}, 496)$ & $\mathbf{0 , 7 6 8 6}$ & $\mathbf{C F}_{\mathbf{B}}$ \\
3 & $\mathrm{CF}\left(\mathrm{CF}_{\mathbf{B}}, \mathrm{CF}_{4}\right)$ & $\mathbf{0 , 7 6 8 1 6}+0,54 \times(1-\mathbf{0 , 7 6 8 1 6})$ & $\mathbf{0 , 9 1 6 5 3 7 6}$ & $\mathbf{C F}_{\mathbf{C}}$ \\
4 & $\mathrm{CF}\left(\mathbf{C F}_{\mathbf{C}}, \mathrm{CF}_{5}\right)$ & $\mathbf{0 , 9 1 6 5 3 7 6}+0,54 \times(1-\mathbf{0 , 9 1 6 5 3 7 6})$ & $\mathbf{0 , 9 2 9 0 5 6 9 6}$ & $\mathbf{C F}_{\mathbf{D}}$ \\
\hline
\end{tabular}

Berdasarkan hasil perhitungan $C F_{\text {kombinasi }}$ didapatkan nilai akhir derajat keyakinan $\left(\mathbf{C F}_{\mathbf{D}}\right)$ terhadap penyakit berak kapur sebesar 0,92905696. Nilai keyakinan tersebut mendekati angka 1 (angka 1 menunjukkan keyakinan mutlak) ini artinya bahwa sistem pakar ini sangat yakin bahwa ayam broiler terkena penyakit berak kapur. Jumlah simulasi pengujian dilakukan sebanyak $U_{\text {total }}$ adalah 5 kali dengan input gejala yang berbedabeda. Rekap seluruh hasil simulasi pengujian disajikan pada Tabel 11.

Tabel 11. Hasil Perbandingan Hitung Manual dengan Output Sistem

\begin{tabular}{|c|c|c|c|c|c|c|}
\hline $\begin{array}{c}\text { Percobaan } \\
\text { ke }\end{array}$ & $\begin{array}{l}\text { Input Gejala } \\
\text { dan CFuser }\end{array}$ & $\begin{array}{c}\text { Hasil } \\
\text { Diagnosis Sistem }\end{array}$ & rule & $\begin{array}{c}\text { Hasil } \\
\text { CFmanual }\end{array}$ & $\begin{array}{c}\text { Hasil } \\
\text { CFsistem }\end{array}$ & $\begin{array}{c}\text { Hasil } \\
\text { (CFsesuai) }\end{array}$ \\
\hline 1 & $\begin{array}{l}\mathrm{G} 8=0.6, \mathrm{G} 9=0.7, \mathrm{G} 10=0.8, \\
\mathrm{G} 17=0.5, \mathrm{G} 22=0.6, \\
\mathrm{G} 24=0.8, \mathrm{G} 26=0.5\end{array}$ & Berak kapur & sesuai & 0,92905696 & 0,92 & sesuai \\
\hline 2 & $\begin{array}{l}\mathrm{G} 7=0.8, \mathrm{G} 9=0.8, \mathrm{G} 10=0.2, \\
\mathrm{G} 14=0.6, \mathrm{G} 15=0.6\end{array}$ & $\begin{array}{l}\text { Newcastle } \\
\text { disesase }\end{array}$ & sesuai & 0,900043264 & 0,90 & sesuai \\
\hline 3 & $\begin{array}{l}\mathrm{G} 9=1, \mathrm{G} 10=0.2, \mathrm{G} 17=0.8, \\
\mathrm{G} 18=0.8, \mathrm{G} 19=0.6\end{array}$ & Gumboro & sesuai & 0,885291028 & 0,88 & sesuai \\
\hline 4 & $\begin{array}{l}\mathrm{G} 9=0.8, \mathrm{G} 10=0.2, \mathrm{G} 14=0.6, \\
\mathrm{G} 17=0.8, \mathrm{G} 22=0.6, \\
\mathrm{G} 23=0.8, \mathrm{G} 24=0.4, \\
\mathrm{G} 25=0.8, \mathrm{G} 26=0.8, \\
\mathrm{G} 27=0.6\end{array}$ & Berak kapur & sesuai & 0,995025944 & 0,99 & sesuai \\
\hline 5 & $\begin{array}{l}\mathrm{G} 1=0,7, \mathrm{G} 2=0,5, \mathrm{G} 3=0,4, \\
\mathrm{G} 4=0,9, \mathrm{G} 5=0,3\end{array}$ & Ngorok & sesuai & 0,8764 & 0,88 & sesuai \\
\hline
\end{tabular}


Berdasarkan rekap data pada Tabel 11 hasil diagnosis sistem pakar dengan metode forward chaining menunjukkan bahwa output yang sesuai dengan rancangan rule $R_{\text {sesuai }}$ berjumlah 5 , dan hasil metode certainty factor untuk nilai derajat kepercayaan sistem pakar yang sesuai dengan hasil hitung manual $C F_{\text {sesuai }}$ berjumlah 5. Maka hasil persentase validasi output sistem dihitung menggunakan persamaan (3) adalah sebagai berikut:

1. Persentase kesesuaian rule:

$$
\text { Validasi }_{\text {output }}=\frac{R_{\text {sesuai }}}{U_{\text {total }}} \times 100 \%=\frac{5}{5} \times 100 \%=100 \%
$$

2. Persentase kesesuaian derajat kepercayaan:

$$
\text { Validasi }_{\text {output }}=\frac{C F_{\text {sesuai }}}{U_{\text {total }}} \times 100 \%=\frac{5}{5} \times 100 \%=100 \%
$$

Berdasarkan hasil perhitungan Validasi $_{\text {output }}$ baik kesesuaian rule maupun nilai deajat kepercayaan diperoleh nilai $100 \%$, ini berarti bahwa purwarupa yang dihasilkan sudah sesuai dengan rancangan model basis pengetahuan.

Untuk mengetahui dampak penggunaan pemberian nilai bobot gejala dari pengguna, dilakukan simulasi pengujian yang membandingkan hasil pengujian tanpa $C F_{\text {user }}$ dengan hasil pengujian yang menggunakan $C F_{\text {user }}$. Untuk keperluan pengujian ini, pada percobaan ke-5 (Tabel 11) nilai tanpa $C F_{\text {user }}$ diatur bernilai 1 . Hal tersebut menyatakan bahwa pengguna menganggap bahwa gejala-gejala fisik yang diamati benar-banar dialami oleh ayam broiler. Hasil perbandingan pengujian tersebut disajikan pada Tabel 12.

Tabel 12. Perbandingan Pengujian Tanpa Nilai $C F_{\text {user }}$ dan dengan $C F_{\text {user }}$

\begin{tabular}{clcccccc}
\hline Penyakit & Pengaturan & G1 & G2 & G3 & G4 & G5 & CFakhir \\
\hline Ngorok & Tanpa CFuser & 1 & 1 & 1 & 1 & 1 & 0,9937 \\
Ngorok & Dengan CFuser & 0,7 & 0,5 & 0,4 & 0,9 & 0,3 & 0,8764 \\
\hline
\end{tabular}

Hasil pengujian pada Tabel 12 menunjukkan bahwa pemberian nilai bobot gejala dari pengguna $\left(C F_{\text {user }}\right)$ berdampak pada penurunan nilai derajat kepercayaan terhadap hasil diagnosis. Namun demikian, nilai bobot derajat kepercayaan mutlak (bernilai 1) bukanlah hal yang selalu ditemukan dalam dunia nyata.

Contoh antarmuka hasil diagnosis untuk percobaan ke-5 pada Tabel 11 jika diuji tanpa nilai $C F_{\text {user }}$ ditunjukkan pada Gambar 6, dimana tingkat kepercayaannya dinyatakan dalam persen dan menampilkan informasi cara penanganan (solusi) penyakitnya. Tingkat kepercayaan sangat yakin berarti nilai $C F_{\text {user }}$ diatur dengan nilai mutlak 1 .

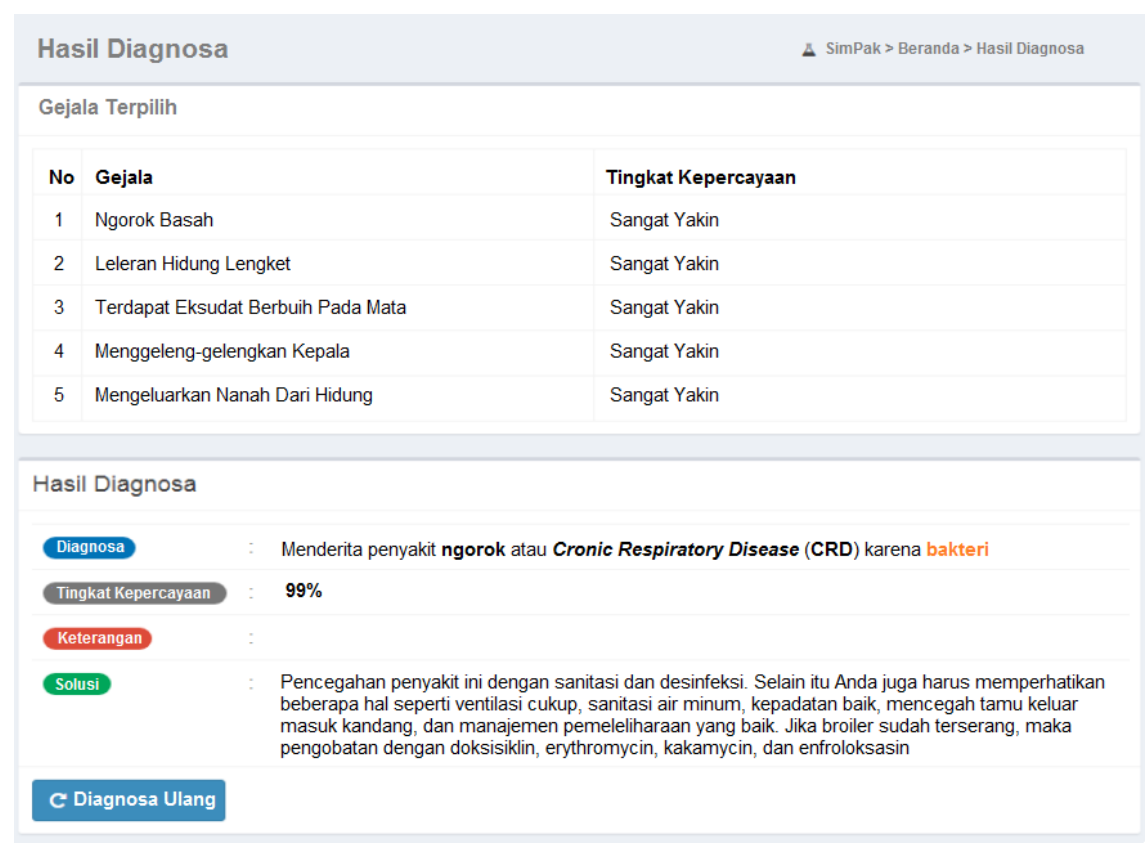

Gambar 6. Antarmuka halaman hasil diagnosis 


\section{KESIMPULAN}

Berdasarkan hasil dari simulasi dan analisis data dapat disimpulkan bahwa purwarupa sistem pakar yang telah dibuat dengan menerapkan metode forward chaining serta certainty factor dapat mendiagnosis jenis penyakit ayam broiler berdasarkan gejala-gejala yang dimasukkan oleh pengguna. Output diagnosis yang dihasilkan oleh sistem pakar dalam 5 kali percobaan menunjukan kesesuaian $100 \%$ antara hasil pengujian dengan rancangan model basis pengetahuan yang dibangun. Hal tersebut membuktikan bahwa purwarupa yang dibuat sudah berfungsi dengan baik dan benar. Selain itu, nilai bobot gejala yang diperoleh dari pengguna berpengaruh terhadap besarnya nilai derajat keyakinan pada hasil diagnosis dan nilainya lebih rendah bila dibandingkan dengan kondisi ideal. Saran penelitian selanjutnya yaitu perlu dilakukan pengujian akurasi dengan membandingkan output sistem dengan jawaban dari pakar sehingga sistem pakar ayam broiler ini dapat diketahui tingkat akurasi kesalahan diagnosisnya secara nyata.

\section{UCAPAN TERIMA KASIH}

Terimkasih penulis ucapkan kepada Universitas Bumigora atas dukungan untuk menyelesaikan penelitian yang penulis lakukan.

\section{REFERENSI}

[1] M. Nurdiman, A. R. Daulay, and L. Ermansyah, Eds., Statistik Peternakan dan Kesehatan Hewan Tahun 2019. Jakarta: Direktorat Jenderal Peternakan dan Kesehatan Hewan Kementerian Pertanian RI, 2019.

[2] F. Tamalluddin, Panduan Lengkap Ayam Broiler, 11th ed. Jakarta: Penebar Swadaya, 2016.

[3] S. Saptana, A. Basuno, and Y. Yusdja, "Dampak Ekonomi Flu Burung Terhadap Kinerja Industri Perunggasan di Provinsi Jawa Tengah,” Jurnal Sosial Ekonomi Pertanian, vol. 5, no. 3, 2005.

[4] J. Rahmah and R. A. Saputra, "Penerapan Certainty Factor Pada Sistem Pakar Diagnosa Penyakit Saluran Pencernaan Ayam Broiler,” Jurnal Informatika, vol. 4, no. 1, pp. 94-102, 2017.

[5] D. P. S. Setyohadi, R. A. Octavia, and T. D. Puspitasari, “An Expert System for Diagnosis of Broiler Diseases using Certainty Factor," Journal of Physics: Conference Series, vol. 953, p. 012118, Jan. 2018.

[6] G. Ginting and S. Subuh Hati Tarigan, "Sistem Pakar Mendiagnosa Penyakit Gumboro Pada Ayam Broiler Dengan Metode Certainty Factor,” Jurnal Media Informatika Budidarma, vol. 1, no. 2, pp. 5457, 2017.

[7] S. P. R. Said, I. G. P. S. Wijaya, and F. Bimantoro, "Implementasi Metode Dempster Shafer pada Sistem Pakar Diagnosis Penyakit Ayam,” Journal of Computer Science and Informatics Engineering, vol. 4, no. 1, pp. 26-35, Jun. 2020.

[8] A. Afandi, "Sistem Pakar Identifikasi Penyakit Ayam Pedaging," Jurnal Cendikia, vol. 16, no. 1, pp. 58-67, 2018.

[9] F. Ariani, M. Marpitalia, E. Erlangga, and Y. Yulfriwini, "Sistem Pakar Diagnosa Penyakit Pada Ayam Broiler Dengan Metode Forward Chaining," Expert : Jurnal Sistem Informasi, vol. 9, no. 1, pp. 27-32, 2019.

[10] K. E. Setyaputri, A. Fadlil, and S. Sunardi, "Comparative Analysis of Certainty Factor Method and Bayes Probability Method on ENT Disease Expert System," Scientific Journal of Informatics, vol. 5, no. 2, pp. 205-212, Nov. 2018.

[11] I. L. K. Panjaitan, E. Panggabean, and S. Sulindawaty, "Analisis Perbandingan Metode Dempster Shafer dengan Metode Certainty Factor Untuk Mendiagnosa Penyakit Stroke," Journal of Informatic Pelita Nusantara, vol. 3, no. 1, pp. 69-74, 2018.

[12] P. S. Ramadhan and U. F. S. Pane, "Analisis Perbandingan Metode (Certainty Factor, Dempster Shafer dan Teorema Bayes) untuk Mendiagnosa Penyakit Inflamasi Dermatitis Imun pada Anak,” Jurnal Sains Manajemen Informatika dan Komputer, vol. 17, no. 2, pp. 151-157, 2018.

[13] H. Hairani, M. N. Abdillah, and M. Innuddin, "Perancangan Sistem Pakar Diagnosis Penyakit Rematik Menggunakan Inferensi Forward Chaining Berbasis Prolog," InfoTekJar (Jurnal Nasional Informatika dan Teknologi Jaringan), vol. 4, no. 1, pp. 8-11, Sep. 2019.

[14] S. Kusumadewi, Artificial Intelligence (Teknik dan Aplikasinya). Yogyakarta: Graha Ilmu, 2003.

[15] Hairani, M. N. Abdillah, and M. Innuddin, “An Expert System for Diagnosis of Rheumatic Disease Types Using Forward Chaining Inference and Certainty Factor Method," in 2019 International Conference on Sustainable Information Engineering and Technology (SIET), 2019, pp. 104-109.

[16] A. Al-Ajlan, "The Comparison between Forward and Backward Chaining," International Journal of Machine Learning and Computing, vol. 5, no. 2, pp. 106-113, Apr. 2015.

[17] M. Muqorobin, P. B. Utomo, M. Nafi'Uddin, and K. Kusrini, "Implementasi Metode Certainty Factor pada Sistem Pakar Diagnosa Penyakit Ayam Berbasis Android," Creative Information Technology Journal, vol. 5, no. 3, p. 185, Sep. 2019. 
[18] Y. K. Kumarahadi, M. Z. Arifin, S. Pambudi, T. Prabowo, and K. Kusrini, "Sistem Pakar Identifikasi Jenis Kulit Wajah dengan Metode Certinty Factor," Jurnal Teknologi Informasi dan Komunikasi, vol. 8, no. 1, pp. 21-27, 2020. 